\title{
Rusle parameters for modeling the loss of a soil subjected to pig slurry application
}

\author{
Maria Aparecida do Nascimento dos Santos(1), Ildegardis Bertol(1), \\ Danieli Schneiders Kaufmann ${ }^{(1)}$, José Mecabô Júnior ${ }^{(2)}$ and Bárbara Bagio(1)
}

\begin{abstract}
(1)Universidade do Estado de Santa Catarina, Centro de Ciências Agroveterinárias, Avenida Luiz de Camões, no 2.090, Conta Dinheiro, CEP 88520-000 Lages, SC, Brazil. E-mail: mariaagronomia@gmail.com, ildegardis.bertol@udesc.br, danielischneiders@gmail.com, barbarabagio@yahoo.com.br (2)Instituto Federal de Santa Catarina, Campus Lages, Rua Heitor Villa Lobos, № 222, São Francisco, CEP 88506-400 Lages, SC, Brazil. E-mail: josemecabo@yahoo.com.br
\end{abstract}

Abstract - The objective of this work was to determine adjustment parameters for the revised universal soil loss equation (Rusle) of a soil subjected to pig slurry application. Treatments consisted of $0,50,100$, and $200 \mathrm{~m}^{3} \mathrm{ha}^{-1}$ pig slurry (PS), after the cultivation of black oat (Avena strigosa), besides the application of $50 \mathrm{~m}^{3} \mathrm{ha}^{-1} \mathrm{PS}$ for six times onto the soil surface in a temporal sequence, and a control treatment of soil without cultivation and without pig slurry application. The evaluations were performed for black oat shoot dry mass, root mass and crop residues semi-incorporated into the soil (RMR), soil losses by means of simulated rain, and the parameters for water erosion modeling. The pig slurry application onto soil surface caused a reduction in the values of the soil consolidation parameter $\left(\mathrm{C}_{\mathrm{f}}\right)$, an increase in the mass of living and dead roots and cultural residues incorporated in the upper layer $(0.0-0.1 \mathrm{~m})$ of the soil $\left(\mathrm{B}_{\mathrm{u}}\right)$, and a reduction in the subfactor prior land use (PLU) of the Rusle.

Index terms: Avena strigosa, cultural residue factor, mathematical model, simulated rain, soil consolidation factor, water erosion.

\section{Parâmetros Rusle para modelar a perda de um solo submetido à aplicação de dejeto suíno}

Resumo - O objetivo deste trabalho foi determinar parâmetros de ajuste para a equação universal de perda de solo revisada (Rusle) de um solo submetido à aplicação de dejeto líquido de suínos. Os tratamentos consistiram de 0,50, 100 e $200 \mathrm{~m}^{3} \mathrm{ha}^{-1}$ de dejeto líquido de suínos (DLS), após o cultivo de aveia-preta (Avena strigosa), além da aplicação de $50 \mathrm{~m}^{3} \mathrm{ha}^{-1}$ de DLS por seis vezes à superfície do solo, em uma sequência temporal, e de um controle com solo sem cultivo e sem dejeto. As avaliações foram feitas quanto à massa de matéria seca da parte aérea da aveia-preta, à massa de raízes e aos resíduos da cultura semi-incorporados ao solo, às perdas de solo por meio de chuva simulada e aos parâmetros para modelagem de erosão hídrica. A aplicação de dejeto líquido de suínos à superfície do solo causou a diminuição dos valores de consolidação do solo $\left(\mathrm{C}_{\mathrm{f}}\right)$, o aumento da massa de raízes vivas e mortas e dos resíduos culturais incorporados à camada superficial $(0.0-0.1 \mathrm{~m})$ do solo $\left(\mathrm{B}_{\mathrm{u}}\right)$, e a redução dos valores de uso anterior da terra (PLU) na Rusle.

Termos para indexação: Avena strigosa, fator resíduo cultural, modelo matemático, chuva simulada, fator consolidação do solo, erosão hídrica.

\section{Introduction}

The pig slurry (PS) farming stands out in the Brazilian socioeconomic scenario generating countless jobs and income in the producing regions. The country has a herd of about 39 million animals, with approximately $48 \%$ of the production concentrated in the Southern region (ABPA, 2016). In Santa Catarina, the hog population is composed of 5.5 million animals, distributed mainly in the south and west of the state, and producing $47.000 \mathrm{~m}^{3}$ per day of pig slurry (PS) (Produção..., 2014). Creative Commons Attribution 4.0 International License
Currently, the main use of PS generated during the production cycle is its application onto the soil as a fertilizer for crop and pasture, to complement or replace mineral fertilizers recommended by fertilization programs (Agne \& Klein, 2014). However, there is a concern about the dose to be used and its influence on the soil attributes (Arruda et al., 2010). Besides, continued or excess PS can cause environmental damage, such as soil pollution (Condé et al., 2012), increased runoff, and sediment transport (Oliveira et al., 2015).

Pesq. agropec. bras., Brasília, v.53, n.10, p.1167-1176, Oct. 2018 DOI: 10.1590/S0100-204X2018001000010 
The effect of PS on soil properties and water erosion depend on a number of factors, such as dose, type, and composition of PS, season, frequency, and mode of application, soil type, crop requirements, relief, and rainfall regime (Oliveira et al., 2016), which justifies the lack of consensus on the influence of this organic fertilizer on soil and on the erosive process. Some authors concluded that increasing PS doses improve the soil physical (Comin et al., 2013) and chemical (Moraes et al., 2014) properties, also increasing the production of plant biomass and the water movement within the soil (Condé et al., 2013).

Ceretta et al. (2010) found an increase of runoff volume on soil surface, after successive applications of $0,20,40$, and $80 \mathrm{~m}^{3} \mathrm{ha}^{-1} \mathrm{PS}$. While, Mecabô Júnior et al. (2014), when studying water erosion in a notillage system, observed that soil loss (SL) and water losses (WL) were not influenced by the application of PS between 0 and $200 \mathrm{~m}^{3}$ ha $^{-1}$ onto the soil surface.

The above mentioned findings and the lack of agronomic criteria for the use of PS as fertilizer, aiming at its disposal in the soil, draw attention to the need to understand the influence of this management on the erosive process. The model of water erosion calculated through the Rusle, specifically by the factor $\mathrm{C}$ (land cover and management factor) and its subfactor PLU (prior land use), can be used to achieve such understanding. The subfactor PLU expresses the residual effect of land use on water erosion, and it is influenced by soil consolidation and the residue of the shoots and roots of the crops. Its study serve as a basis for the elaboration of conservationist planning for land use and management.

The objective of this work was to determine the adjustment parameters for Rusle of a soil subjected to pig slurry application.

\section{Materials and Methods}

The research was carried out between October 2014 and October 2015, in a region of the Atlantic Forest biome, in a field experiment located between $27^{\circ} 49^{\prime} \mathrm{S}$ and $50^{\circ} 20^{\prime} \mathrm{W}$, at $923 \mathrm{~m}$ altitude. The climate is of type $\mathrm{Cfb}$, according to the classification of Köppen-Geiger, with annual averages of $1,533 \mathrm{~mm}$ precipitation and 5,033 $\mathrm{MJ} \mathrm{mm} \mathrm{ha}{ }^{-1}$ per hour erosivity, at the experiment site (Schick et al., 2014b). The soil is an Inceptisol (Santos et al., 2013), corresponding to a Humic Cambisol according to World... (2006), with $0.0175 \mathrm{t}$ ha h ha ${ }^{-1} \mathrm{MJ}^{-1} \mathrm{~mm}^{-1}$ erodibility (Schick et al., 2014a) and a clay-silt-loam texture (Table 1).

Prior to the experiment, soybean (Glycine $\max L$.) was cultivated between November 2013 and April 2014. In that culture, PS was applied twice, at 0, 50, 100 and $200 \mathrm{~m}^{3} \mathrm{ha}^{-1}$, during the crop cycle. Two additional treatments were conducted, one without cultivation and with PS application at $50 \mathrm{~m}^{3} \mathrm{ha}^{-1}$, and other without cultivation and without PS application. Simulated rainfall was carried out on the top of the treatments, during the soybean crop cycle, for another erosion study. Between April and September of 2014, in the same area, black oat (Avena strigosa Schreb.) was grown in no-tillage system on the soybean residues. The oat culture was managed in September 2014 by hand-cutting, at the grain development stage. Oat residues were kept on the soil. In the treatment without crop, the soil remained fallow and clean. During the oat cycle, no PS was applied. And finally, in October 2014, at the beginning of this research, the soil was prepared with a light harrowing, followed by a chiseling and another slight harrowing.

The treatments consisted of two replicates according to the PS doses, as follows: soil with crop [without manure (CD0), with $50 \mathrm{~m}^{3} \mathrm{ha}^{-1} \mathrm{PS}$ (CD50), with 100 $\mathrm{m}^{3} \mathrm{ha}^{-1}$ PS (CD100), and with $200 \mathrm{~m}^{3} \mathrm{ha}^{-1} \mathrm{PS}$ (CD200)]; 2) soil without crop [without PS (WCD0), or with 50 $\mathrm{m}^{3} \mathrm{ha}^{-1} \mathrm{PS}$ (WCD50)]. These doses were applied in the plots that had received the same doses of PS in the soybean cultivation. Each dose of PS was applied six times during this phase, each one preceding in one day each of the simulated rainfall. PS was composed of a mixture of feces, urine, and water and debris from the swine facilities cleaning, and was applied manually onto the soil with the aid of irrigators. The values of $\mathrm{pH}$ and dry matter of pig slurry in the solid + liquid fractions were 7.0 and $0.38 \%$, respectively. The concentrations of $\mathrm{NO}_{3}^{-}, \mathrm{NH}_{4}^{+}, \mathrm{P}$, and $\mathrm{K}-$ in the solid fraction $\left(\mathrm{mg} \mathrm{kg}^{-1}\right)$ and liquid fraction $\left(\mathrm{mg} \mathrm{L}^{-1}\right)-$ were, respectively, the following ones: 11,905 and 7.23, nondetected and 31.82, 377 and 0.22, 5,444 and 21.31, and 26,120 and 86.18 .

Each experimental unit, Wischmeier plot is characterized by $11 \mathrm{~m}$ length in the slope direction, and $3.5 \mathrm{~m}$ width, delimited on the sides and the top edge by galvanized sheets of $0.2 \mathrm{~m}$ height buried $0.1 \mathrm{~m}$ into the ground; the lower end was delimited by a collecting trough that was connected to a pipeline and directed 
the runoff flow to the place where the measurements and drained material collections were carried out, according to Wischmeier \& Smith (1978). Each pair of plots was arranged with a $3.5 \mathrm{~m}$ interval between them, where the rainfall simulator was positioned.

Over 354 days of field work, six simulated rainfall tests were performed, with six rainfall events for each test (one rainfall per treatment), totaling 36 rainfalls on the following dates: $10 / 25 / 2014,01 / 17 / 2015,03 / 20 / 2015$, $05 / 15 / 15,07 / 30 / 2015$, and 10/13/15. Each rainfall had of $60 \mathrm{~min}$ of duration, and a constant intensity planned for $65 \mathrm{~mm}$ per hour. To carry out the rainfall, a Thrusttype rainfall simulator with rotary arms developed by Bertol et al. (2012) was used.

On the day before each simulated rainfall test, a soil sample was collected in each plot, resulting from the composition of five subsamples, at $0-0.1 \mathrm{~m}$ soil depth, with the aid of a Dutch-type soil auger. After collection, in the laboratory, the samples were crushed and the root mass and residues semi-incorporated by the preparation (RMR) were separated from the soil and quantified as described in Streck (1999).

During the execution of each of the simulated rainfalls, samples from the runoff were collected, at the runoff beginning using plastic pots with $0.8 \mathrm{~L}$ capacity; the collection interval of these samples was five min. Subsequently, in the laboratory, the samples were processed, and the soil losses were calculated.

In the Rusle the soil loss is estimated by in which: $\mathrm{A}=$ R.K.L.S.C.P, $\mathrm{A}$ is the annual average $\mathrm{SL}\left(\mathrm{Mg} \mathrm{ha}^{-1}\right)$; $\mathrm{R}$ is the rainfall erosivity factor $\left(\mathrm{MJ} \mathrm{mm} \mathrm{ha} \mathrm{m}^{-1}\right.$ per hour); $\mathrm{K}$ is the soil erodibility factor $\left(\mathrm{Mg}\right.$ ha h ha-1 $\mathrm{MJ}^{-1}$

Table 1. Inceptisol soil properties after the application of pig slurry (PS) treatments.

\begin{tabular}{|c|c|c|c|c|c|c|c|c|c|c|c|}
\hline \multirow{2}{*}{$\begin{array}{l}\text { Layer } \\
(\mathrm{cm})\end{array}$} & \multicolumn{11}{|c|}{ Soil properties } \\
\hline & $\begin{array}{c}\mathrm{pH} \\
\text { water }\end{array}$ & $\begin{array}{c}\mathrm{P} \\
\left(\mathrm{mg} \mathrm{dm}^{-3}\right)\end{array}$ & $\mathrm{Ca}$ & $\mathrm{Mg}$ & $\begin{array}{r}\mathrm{Al} \\
\mathrm{C}\end{array}$ & $\begin{array}{c}\mathrm{H}+\mathrm{Al} \\
\left.\mathrm{m}^{-3}\right)---\end{array}$ & K & CEC & $\begin{array}{l}\text { WAD } \\
(\mathrm{mm})\end{array}$ & $\begin{array}{c}\mathrm{TP} \\
(\%)\end{array}$ & $\begin{array}{c}\mathrm{BD} \\
\left(\mathrm{g} \mathrm{cm}^{-3}\right)\end{array}$ \\
\hline & \multicolumn{11}{|c|}{ CD200, with crop and $200 \mathrm{~m}^{3} \mathrm{ha}^{-1} \mathrm{PS}$} \\
\hline $0-2.5$ & 5.3 & 24.5 & 9.4 & 1.6 & 1.0 & 6.8 & 0.5 & 18.3 & 5.5 & 69 & 1.13 \\
\hline $2.5-5$ & 5.4 & 13.1 & 12.0 & 0.9 & 1.0 & 6.5 & 0.3 & 19.7 & 5.7 & 63 & 1.15 \\
\hline $5-10$ & 5.1 & 9.2 & 8.7 & 3.2 & 0.9 & 6.3 & 0.2 & 18.3 & 5.6 & 57 & 1.19 \\
\hline \multirow[t]{2}{*}{$10-20$} & 5.0 & 11.9 & 7.2 & 1.9 & 1.5 & 9.2 & 0.3 & 18.5 & 5.5 & 59 & 1.18 \\
\hline & \multicolumn{11}{|c|}{ CD100, with crop and $100 \mathrm{~m}^{3} \mathrm{ha}^{-1} \mathrm{PS}$} \\
\hline $0-2.5$ & 5.5 & 13.4 & 9.3 & 0.9 & 0.7 & 5.8 & 0.4 & 16.4 & 6.0 & 62 & 1.38 \\
\hline $2.5-5$ & 5.3 & 6.9 & 9.4 & 1.7 & 0.7 & 6.6 & 0.2 & 17.9 & 6.1 & 63 & 1.23 \\
\hline $5-10$ & 5.2 & 7.8 & 7.9 & 2.0 & 1.4 & 9.6 & 0.2 & 19.7 & 6.1 & 55 & 1.15 \\
\hline \multirow[t]{2}{*}{$10-20$} & 5.1 & 4.6 & 6.8 & 0.9 & 1.6 & 10.0 & 0.3 & 18.0 & 6.0 & 57 & 1.21 \\
\hline & \multicolumn{11}{|c|}{ CD50, with crop and $50 \mathrm{~m}^{3} \mathrm{ha}^{-1} \mathrm{PS}$} \\
\hline $0-2.5$ & 5.9 & 6.2 & 8.9 & 1.5 & 0.0 & 3.5 & 0.5 & 14.3 & 6.2 & 61 & 1.25 \\
\hline $2.5-5$ & 5.6 & 5.1 & 8.5 & 3.7 & 0.3 & 4.8 & 0.3 & 17.3 & 6.4 & 63 & 1.14 \\
\hline $5-10$ & 5.8 & 8.2 & 8.3 & 1.6 & 0.5 & 6.1 & 0.3 & 16.3 & 6.3 & 58 & 1.14 \\
\hline \multirow[t]{2}{*}{$10-20$} & 5.7 & 7.3 & 7.6 & 1.9 & 0.8 & 7.2 & 0.3 & 17.0 & 6.5 & 61 & 1.11 \\
\hline & \multicolumn{11}{|c|}{ CD0, with crop, without PS } \\
\hline $0-2.5$ & 5.5 & 5.3 & 10.3 & 1.9 & 0.3 & 5.3 & 0.4 & 17.8 & 6.6 & 59 & 1.25 \\
\hline $2.5-5$ & 5.7 & 4.9 & 10.5 & 2.6 & 0.1 & 5.3 & 0.2 & 18.6 & 6.4 & 60 & 1.28 \\
\hline $5-10$ & 5.8 & 3.5 & 10.5 & 3.0 & 0.1 & 4.6 & 0.2 & 18.2 & 6.5 & 56 & 1.21 \\
\hline \multirow[t]{2}{*}{$10-20$} & 5.5 & 6.1 & 8.6 & 1.5 & 0.7 & 6.1 & 0.3 & 16.5 & 6.6 & 55 & 1.22 \\
\hline & \multicolumn{11}{|c|}{ WCD50, without crop, with $50 \mathrm{~m}^{3} \mathrm{ha}^{-1} \mathrm{PS}$} \\
\hline $0-2.5$ & 5.6 & 4.5 & 10.7 & 1.1 & 0.1 & 4.0 & 0.4 & 16.2 & 4.8 & 65 & 1.09 \\
\hline $2.5-5$ & 5.7 & 5.2 & 9.7 & 2.0 & 0.1 & 5.6 & 0.5 & 17.8 & 6.2 & 60 & 1.31 \\
\hline $5-10$ & 5.6 & 11.2 & 9.8 & 1.5 & 0.1 & 4.5 & 0.5 & 16.2 & 6.1 & 57 & 1.38 \\
\hline \multirow[t]{2}{*}{$10-20$} & 5.4 & 12.6 & 8.7 & 2.8 & 0.5 & 6.5 & 0.5 & 18.5 & 6.2 & 55 & 1.41 \\
\hline & \multicolumn{11}{|c|}{ WCD0, without crop, without PS } \\
\hline $0-2.5$ & 4.9 & 3.9 & 6.6 & 1.5 & 2.7 & 13.0 & 0.3 & 21.3 & 6.5 & 63 & 1.24 \\
\hline $2.5-5$ & 4.9 & 4.1 & 6.9 & 4.6 & 2.5 & 12.3 & 0.2 & 24.0 & 7.0 & 60 & 1.22 \\
\hline $5-10$ & 5.2 & 3.6 & 6.7 & 2.7 & 2.5 & 11.6 & 0.2 & 21.1 & 6.9 & 55 & 1.24 \\
\hline $10-20$ & 5.2 & 6.2 & 8.9 & 2.9 & 1.3 & 8.3 & 0.5 & 20.5 & 7.3 & 55 & 1.28 \\
\hline
\end{tabular}

$\mathrm{CEC}$, cation exchange capacity, at $\mathrm{pH} 7.0 ; \mathrm{pH}$ in water (2:1); and P, Mehlich. TP, total porosity; BD, soil bulk density. 
$\left.\mathrm{mm}^{-1}\right)$; L is the slope length factor (dimensionless); $\mathrm{S}$ is the slope degree factor (dimensionless); $\mathrm{C}$ is the coverage and soil management factor (dimensionless); and $\mathrm{P}$ is the conservationist support practices factor (dimensionless).

Factor C shows five subfactors, as follows: the residual effect of land use and soil management (PLU) ranging from 0 (zero) to 1 (one); ground cover by the plants crown (CC); soil surface cover by crop residues (SC); soil roughness (SR); and soil moisture preceding rainfall (SM). According to Renard et al. (1997), the PLU can be expressed by the equation PLU $=C_{f} \exp ^{\left(-c \cdot B_{u}\right)}$, in which: $C_{f}$ is the soil surface consolidation (dimensionless, varies from 0 to 1 ); $\mathrm{c}$ is the coefficient representing the relative effectiveness of the mass of live and dead roots and cultural residues incorporated in the erosion reduction $\left(\right.$ acre $1 b^{-1}$ ); and $\mathrm{B}_{\mathrm{u}}$ is the mass of living and dead roots and cultural residues incorporated in the upper layer $(0-0.1 \mathrm{~m})$ of the soil (lb acre $\left.{ }^{-1}\right)$.

The soil consolidation parameter $\left(\mathrm{C}_{\mathrm{f}}\right)$ values were obtained by regression, using the exponential equation $\left(y=\mathrm{ae}^{-\mathrm{bx}}\right)$ generated from the graphical relation between the SL values (y-axis - $\mathrm{tha}^{-1}$ ) and those of time (x-axis - day). Dividing the SL values estimated in the regression (y) over time, by the value of the coefficient a of the equation, we obtained the parameter $\mathrm{C}_{\mathrm{f}}$ value, as proposed by Streck (1999).

Renard et al. (1996) presented the variable $B_{u}$ as a result of $B_{u}=B_{a} n_{i} u_{i}$, in which: $B_{a}$ is the mass of shoot residues $\left(\mathrm{lb}\right.$ acre $\left.{ }^{-1}\right) ; \mathrm{n}_{\mathrm{i}}$ is the root mass ratio in the $0-0.1$ $\mathrm{m}$ layer by the total root mass; and $\mathrm{u}_{\mathrm{i}}$ is the total root mass ratio by the total mass of shoot residues.

The dry mass of the cultural residues of the oat shoots was estimated by the equation $\mathrm{Me}=\mathrm{Mb} \exp ^{(-\mathrm{aD})}$, proposed by Stott et al. (1990), assuming $B_{a}=M e$, as follows, in which: Me is the mass of residues at the end of a period of time $\left(\mathrm{Mg} \mathrm{ha}^{-1}\right) ; \mathrm{Mb}$ is the mass $\left(\mathrm{Mg} \mathrm{ha}^{-1}\right)$ at the beginning of the period; $a$ is the coefficient that depends on the residue characteristics, found in the Rusle database; and D is the time (day).

By means of the graphical relation between the values of $C_{f}$ and $B_{u}$, exponential equations were generated, from which the values of the coefficient $b$ were taken as equal to those of the coefficient $\mathrm{c}$ of the PLU equation, meaning that the mass of live and dead roots and incorporated cultural residues favored the soil consolidation. More consolidated soils show a greater resistance to water erosion than less consolidated ones, according to Renard et al. (1997). Exponential models were adjusted to the data to relate the effect of PS doses on SL and on the Rusle's subfactor PLU parameters over time.

\section{Results and Discussion}

The yield of black oat shoot dry matter (DM) was $3.24,2.99,2.07$, and $1.82 \mathrm{Mg} \mathrm{ha}^{-1}$, in the treatments CD200, CD100, CD50, and CD0, respectively, evidencing the PS effect (Figure 1), in which DM was $78 \%$ higher in the CD200 treatment than in the CD0. This effect was further evidenced by the $14 \%$ increase of DM in the CD50, in comparison to CD0, whose results are in agreement with those found by Steiner et al. (2009).

The DM decomposed throughout the study time (Figure 1), and the estimated values indicate an exponential decrease of $94 \%$, regardless of the PS dose applied. This reduction occurred due to the direct contact of the residue pieces with the soil, whose exposure to humidity and temperature stimulated the microbiological activity, resulting in a final value of approximately $0.25 \mathrm{Mg} \mathrm{ha}^{-1} \mathrm{DM}$. Therefore, at the research period end, the soil became less protected by the residues and more susceptible to erosion in relation to the beginning of the experiment.

The exponential model described satisfactorily the decay of root mass and cultural residues semiincorporated into the soil (RMR) over time (Figure 1), according to Renard et al. (1997), but differing from what was observed by Streck (1999), who obtained a better correlation between these variables using the potency-type model. On the occasion of th $\mathrm{e} 1^{\text {st }}$ simulated rainfall test, RMR values were higher in the higher doses of PS (Figure 1). Thus, in the treatments $\mathrm{CD} 0$ and CD50, especially in which the mass production was smaller, practically all RMR was incorporated into the soil in the layer of preparation by the chiseling $(0-0.18 \mathrm{~m})$. With the consequent temperature increase at this soil depth and the contact of the plant material with the putrefactive microbiota, there was an increase of the rate of vegetal mass decomposition and soil surface exposure to the action of erosive agents.

At 354 days of the experiment, the RMR in the $0-0.1 \mathrm{~m}$ soil layer reduced by $80,73,57$, and $81 \%$ in the treatments CD200, CD100, CD50, and CD0, 

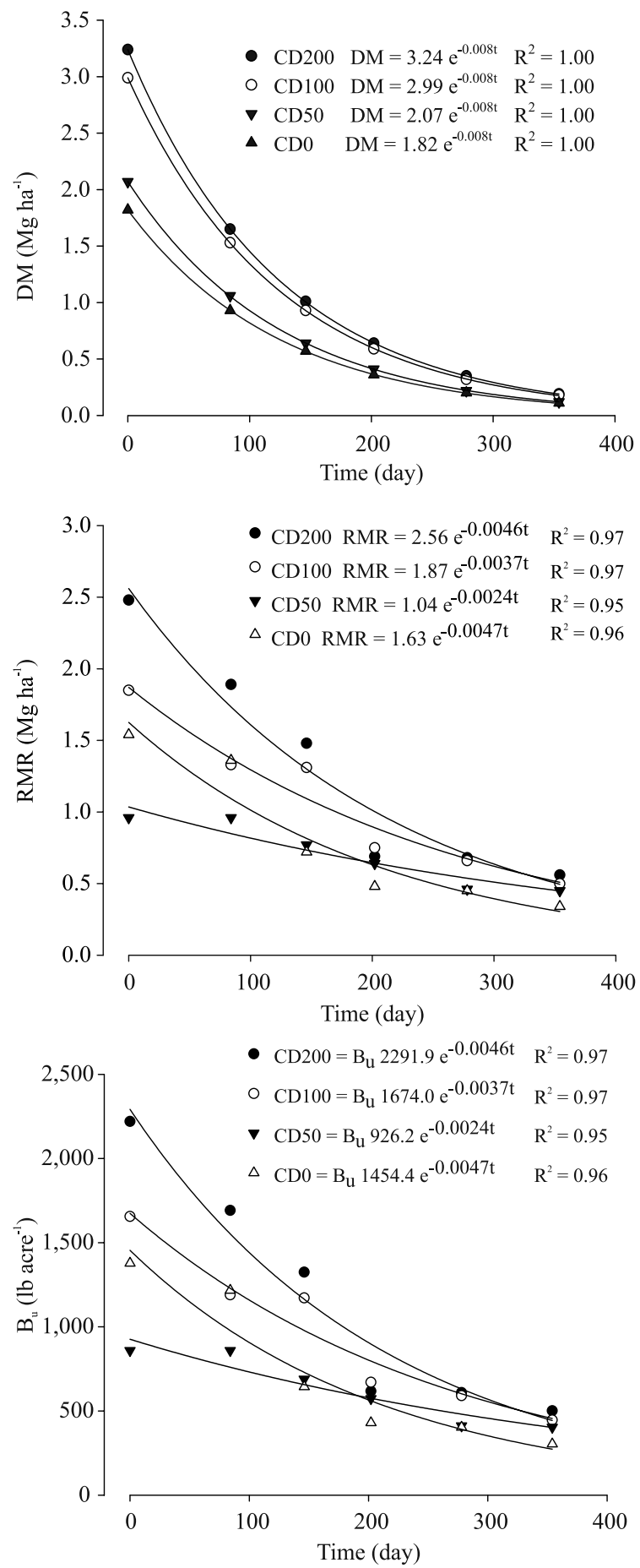

Figure 1. The area ratio of dry mass of residues (DM), root mass and residuals incorporated in the $0-0.1 \mathrm{~m}$ soil depth (RMR), and the incorporated root mass and residues $\left(\mathrm{B}_{\mathrm{u}}\right)$ over time (t) for black oat (Avena strigosa), in an Inceptisol subjected to pig slurry (PS) application and simulated rainfall, in the following treatments: CD200, with crop and $200 \mathrm{~m}^{3} \mathrm{ha}^{-1} \mathrm{PS}$; CD100, with crop and $100 \mathrm{~m}^{3} \mathrm{ha}^{-1} \mathrm{PS}$; CD50, with crop and $50 \mathrm{~m}^{3} \mathrm{ha}^{-1} \mathrm{PS}$; and CD0, with crop and without PS treatments. respectively (Figure 1). The PS is rich in N, according to Moraes et al. (2014). Therefore, when applying cultural residues with high- $\mathrm{C} / \mathrm{N}$ ratio on the top of the manure, the rate of residue decomposition increases, according to Silva et al. (2014). Thus, the soil till adopted in the research (chiseling), associated to the PS action, contributed to the reduction of RMR values (Figure 1) and, as a consequence, to the increase of water erosion.

The main expected consequence of soil protection reduction due to the cultural residue decomposition over time would be the temporal SL increase, according to Wischmeier \& Smith (1978) and Renard et al. (1997). However, the soil surface consolidation kept its resistance to erosion high, with a consequent SL reduction.

The $B_{u}$ parameter values were higher in the CD200 and CD100 treatments and decreased over the study time (Figure 1). Although the CD50 treatment showed higher DM, the RMR at $0-0.1 \mathrm{~m}$ soil depth was lower than that of the $\mathrm{CD} 0$, at the beginning of the experiment, and at 84 days from the beginning, justifying the lower values of $B_{u}$ in that period. At the research end (354 days), the amount of cultural residues was higher in the treatments with higher doses of PS.

The SL decreased from the $3^{\text {rd }}$ rain test onwards, in all treatments, reaching minimum values at the end of the experiment (Figure 2). This is explained by the soil surface conditions, especially by the roughness, cultural residues, rill erosion, and surface crust formation, as well as by the soil consolidation itself, according to Bertol et al. (2008) and Ramos et al. (2014). Over time, SL decreased exponentially, and the highest decreases were observed in CD200 and CD50, although there were increases until the $146^{\text {th }}$ day (data not apparent in Figure 2). Thus, with the reduction of water infiltration in the soil and volume increase and runoff turbulence from the $146^{\text {th }}$ day on, the rill formation in the soil surface increased, which, consequently, accentuated the runoff erosion capacity.

From the $202^{\text {nd }}$ day of the research conduction, there was a reduction of SL (Figure 2), explained by the fact that the readily available material was largely transported before this moment, and by the soil consolidation, according to Streck (1999), Streck \& Cogo (2003), and Volk (2006). After the end of till operation effect, at the beginning of the experiment,

Pesq. agropec. bras., Brasília, v.53, n.10, p.1167-1176, Oct. 2018 DOI: 10.1590/S0100-204X2018001000010 
when the soil was left fallow to consolidate, SL tended to decrease progressively as a result of the increase of soil resistance to shearing, as shown by Renard et. al. (1997). Overall, SL were little affected by the PS doses (Figure 2). However, the PS doses affected SL indirectly, as they influenced the crop development, which reflected on DM and on soil cover.

The $\mathrm{C}_{\mathrm{f}}$ value was considered equal to one (1.00), at the time of the research beginning, which occurred immediately after the soil till and before the beginning of the first simulated rainfall test because, at that moment, the soil had been newly and fully tilled. According to Dissmeyer \& Foster (1981) and Renard et al. (1997), in this condition the soil has a $\mathrm{C}_{\mathrm{f}}$ factor equal to one, decreasing over time until stabilizing, when consolidation is complete. In this case, the soil consolidation occurred over the research time, and $\mathrm{C}_{\mathrm{f}}$ values were higher in the treatments with crop and that had received some dose of PS.

The reduction of erosion at 354 days was 66,58 , $72,31,38$, and $32 \%$, in CD200, CD100, CD50, CD0, WCD50, and WCD0, respectively, in comparison to the research beginning due to soil consolidation (Figure 3). The values of $\mathrm{C}_{\mathrm{f}}$ in the treatments $\mathrm{CD} 0$ and

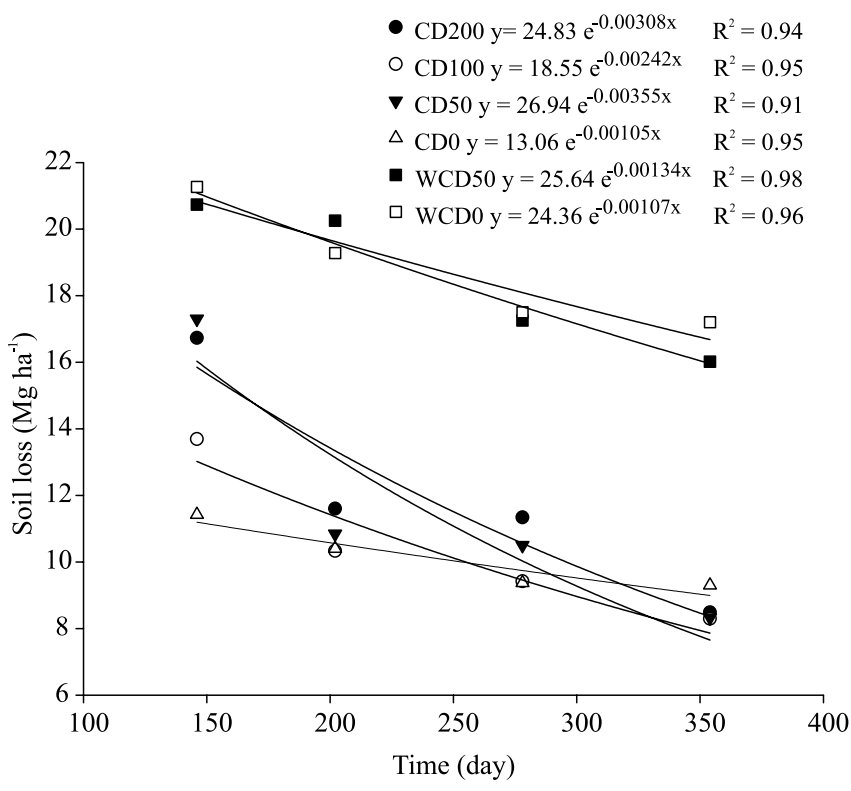

Figure 2. The ratio of soil loss (SL) over time, in an Inceptisol subjected to pig slurry (PS) application and simulated rainfall, in the following treatments: CD200, with crop and $200 \mathrm{~m}^{3} \mathrm{ha}^{-1} \mathrm{PS}$; CD100, with crop and $100 \mathrm{~m}^{3} \mathrm{ha}^{-1}$ PS; CD50, with crop and $50 \mathrm{~m}^{3} \mathrm{ha}^{-1} \mathrm{PS}$; CD0, with crop and without PS; WCD50, without crop and with $50 \mathrm{~m}^{3} \mathrm{ha}^{-1} \mathrm{PS}$; and WCD0, without crop and without PS treatments.
WCD0 were similar to each other, reducing erosion temporally in a similar way. This suggests that there was an effect of the PS doses on the soil consolidation process, as higher doses increased the production of oat biomass (DM and RMR). In particular, DM initially kept the soil surface protected against rain energy, but during decomposition, this residue probably released humic and binding substances, which aggregated the soil and increased resistance to erosion.

In the CD50 treatment, there was more soil consolidation than in the others (Figure 3), at the end of the study (354 days), due to the slow decomposition of roots and cultural residues incorporated in the soil. Thus, the slow decomposition of this biomass maintained the benefit for a longer period of time, unlike what occurred in the treatments with higher doses of PS, in which the decomposition was faster. In the CD0 treatment, the amount of cultural residues produced was inferior to the other treatments with crop. Even so, the rate of vegetal mass decomposition was similar to the CD50, due to the smaller amount of water added to the soil surface via manure in this treatment, compared to those with higher doses.

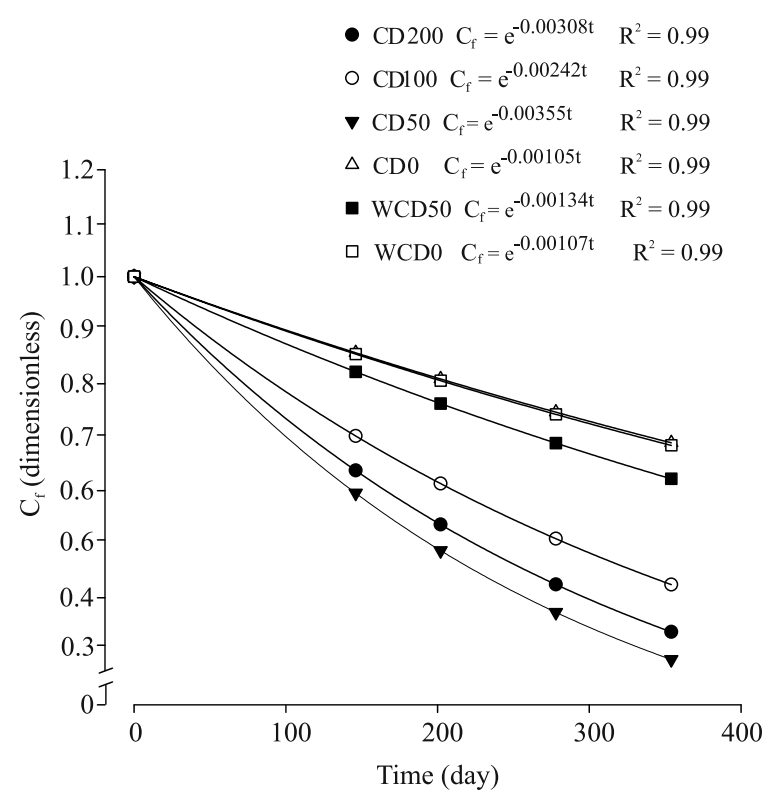

Figure 3. The ratio between consolidation factor $\left(\mathrm{C}_{\mathrm{f}}\right)$ and time (t), in an Inceptisol subjected to pig slurry (PS) application and simulated rainfall, in the following treatments: CD200, with crop and $200 \mathrm{~m}^{3} \mathrm{ha}^{-1} \mathrm{PS}$; CD100, with crop and $100 \mathrm{~m}^{3}$ $\mathrm{ha}^{-1} \mathrm{PS}$; CD50, with crop and $50 \mathrm{~m}^{3} \mathrm{ha}^{-1} \mathrm{PS}$; CD0, with crop and without PS; WCD50, without crop and with $50 \mathrm{~m}^{3} \mathrm{ha}^{-1}$ PS; and WCD0, without crop and without PS treatments. 
Values of $\mathrm{C}_{\mathrm{f}}$ equal to 0.07 (with crop) and 0.19 (without crop) were found by Streck (1999) for reconsolidation treatments, after 869 days of evaluation. By estimating the values of $\mathrm{C}_{\mathrm{f}}$ for $\mathrm{CD0}$ and WCD0 (Figure 3), treatments that are relatively similar to those found by the abovementioned author, for the same period of time, $\mathrm{C}_{\mathrm{f}}=0.40(\mathrm{CD} 0)$ and $\mathrm{C}_{\mathrm{f}}=0.39$ (WCD0), were obtained, meaning that the studied soil (Humic Cambisol) consolidated more slowly. However, data obtained here differed from the results of Dissmeyer $\&$ Foster (1981), whose $C_{\mathrm{f}}$ value for a soil left at rest for seven years was 0.45 . These differences are due to the distinctions in the intrinsic characteristics and history of soil cultivation, and to the local climatic conditions that have clearly affected the vegetal decomposition and the soil mass expansion/contraction.

The values of coefficient c (Figure 4) resemble those presented by Renard et al. (1997) in the Agriculture Handbook 703 as $\mathrm{c}_{\mathrm{ur}}=0.00199$ and $\mathrm{c}_{\mathrm{us}}=0.000416$ acre $\mathrm{lb}^{-1}$. However, they differ from those found by Cogo \& Streck (2003), -0.0010 and -0.0012 , as well as by Volk (2006), -0.0013 and -0.0048 , which are similar to those found in the Rusle data for furrow erosion $(-0.0018)$ and rill erosion combined with erosion between interrill $(-0.0014)$. Such differences in the c values are justified by the different management, cultivation, climate, and soil conditions studied by different authors.
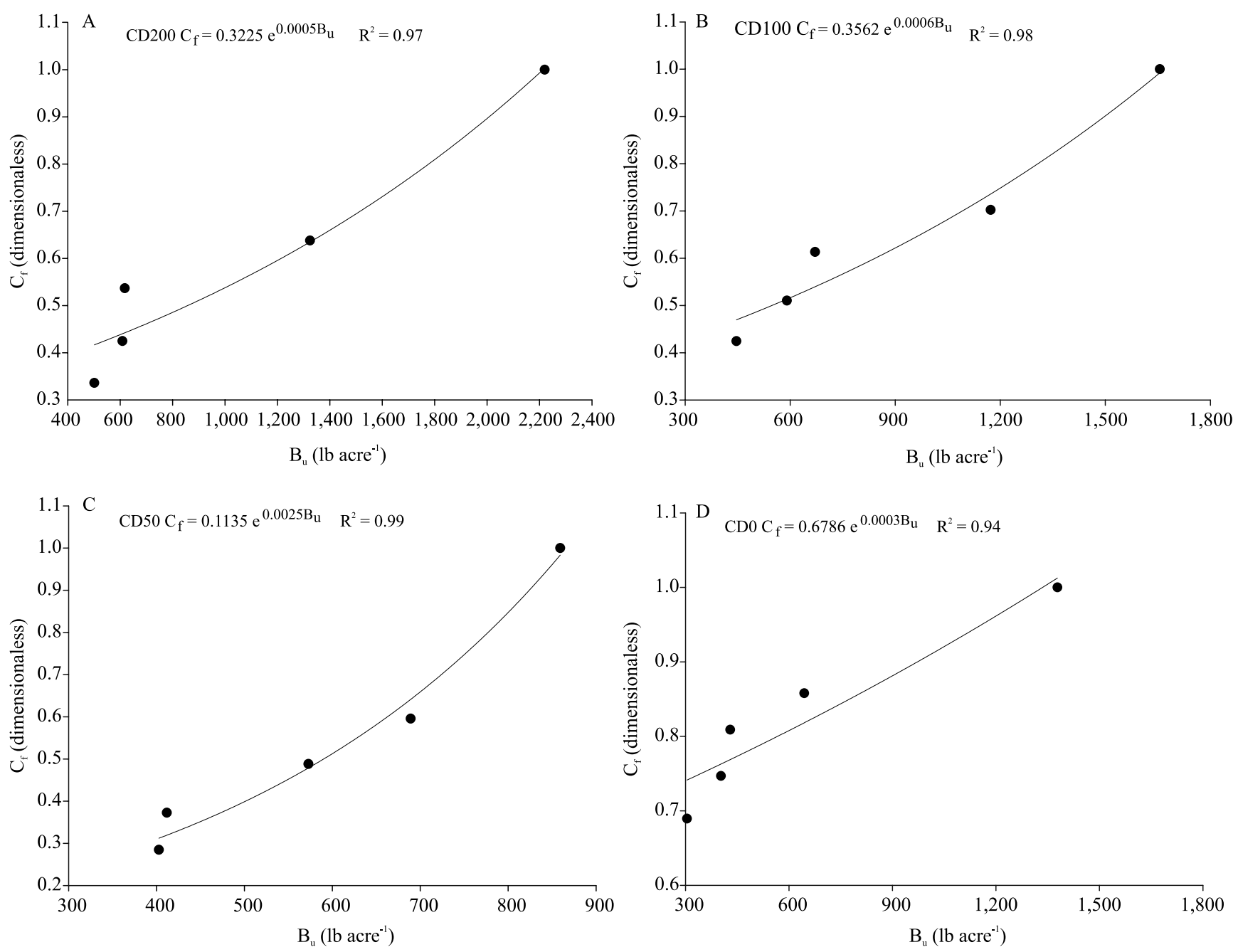

Figure 4. The ratio between $\mathrm{C}_{\mathrm{f}}(\mathrm{y})$ and $\mathrm{B}_{\mathrm{u}}(\mathrm{x})$ variables, in an Inceptisol subjected to pig slurry (PS) application and simulated rainfall, in the following treatments: (a) CD200, with crop and $200 \mathrm{~m}^{3} \mathrm{ha}^{-1} \mathrm{PS}$; (b) CD100, with crop and $100 \mathrm{~m}^{3} \mathrm{ha}^{-1}$ PS; (c) CD50, with crop and $50 \mathrm{~m}^{3} \mathrm{ha}^{-1} \mathrm{PS}$; and (d) CD0, with crop and without PS treatments. 
The PLU expresses the influence of the residual effect of land use and soil management on consolidation and water erosion. In fully and newly mobilized soils, the value of $\mathrm{C}_{\mathrm{f}}$ is equal to one (1.00) and the soil is considered as uncultivated, therefore, in the absence of roots and incorporated cultural residues, the PLU value is also equal to 1.00 , as $P L U=1 \mathrm{exp}^{-0.0}$, resulting in a certain SL value. In cropped soils with cultural residue on the surface, and roots and cultural residues incorporated in the soil, SL are diminished because the consolidation makes the soil more resistant to erosion. In this condition, the PLU subfactor becomes lower than 1.00 (Figure 5), which reflects how much soil use and management reduced SL in relation to the situation of soil without crop and with inversion by till.

At the research beginning, before the $1^{\text {st }}$ rainfall test, the PLU values were higher than at the time of the subsequent tests, for all treatments, in the recently mobilized soil (which was consequently not yet consolidated). Due to this fact, the soil mass on the surface was subjected to transport, and the resistance to shearing was dependent on the

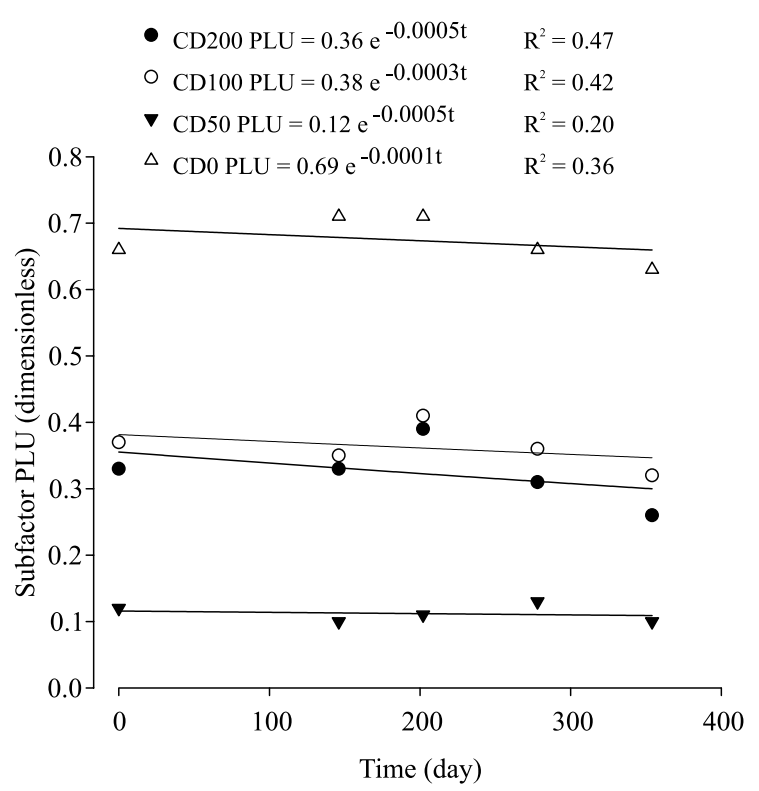

Figure 5. The ratio between the subfactor PLU of the Rusle and time ( $\mathrm{t}$ ), in an Inceptisol subjected to pig slurry (PS) and simulated rainfall, in the following treatments: CD200, with crop and $200 \mathrm{~m}^{3} \mathrm{ha}^{-1} \mathrm{PS}$; CD100, with crop and $100 \mathrm{~m}^{3}$ $\mathrm{ha}^{-1} \mathrm{PS}$; CD50, with crop and $50 \mathrm{~m}^{3} \mathrm{ha}^{-1} \mathrm{PS}$; and CD0, with crop and without PS treatments. surface physical conditions (roughness, aggregates stability, porosity, among others), and on the surface cover and incorporated vegetal mass. Over time, the consolidation increased, reducing PLU values because of the incidence of rainfall, and the influence of wetting and drying cycles, the mass of roots and residues incorporated, and changes in soil structure and density (Figure 5).

At the end of the 354 days of research, the CD0 treatment provided only $27 \%$ reduction of SL by erosion, according to the PLU values (Figure 5), in comparison to the situation without consolidation and crop, in which PLU $=1.00$. This is explained by the lower consolidation and mass of roots and residues incorporated in this treatment in comparison to the others. Besides, in CD50, the SL reduction was $90 \%$ due to the high-soil consolidation, which shows the importance of the consolidation to mitigate the erosive process.

In the CD200 and CD100 treatments, SL reduction were 74 and $68 \%$, respectively, compared to the condition of PLU $=1.00$. In these treatments, the highest values of $B_{u}$ stood out, showing the efficacy of root mass and residues incorporated in the reduction of water erosion, either by its mechanical action, as a physical barrier to free flow, or by the release of exudates acting in the soil aggregation, which corroborates the results of Renard et al. (1997), Streck (1999), Cogo \& Streck (2003), and Volk (2006).

The PS dose increase tended to decrease the PLU values, as it increased the mass of cultural residues shoots and roots of black oat. The cultural residues protected the soil from the rain energy and runoff, after the soil mobilization. In addition, these residues on the soil surface filtered sediments suspended in the runoff and, when incorporated into the soil, they stabilized the soil mass, increasing both the soil consolidation and resistance to rill erosion. However, higher doses of PS stimulated the residue decomposition more than smaller doses and, gradually, decreased the PLU values due to the PLU relation to the variable $B_{u}$.

\section{Conclusions}

1. Pig slurry applied to the soil favors the process of surface consolidation, promoting the reduction of $\mathrm{C}_{\mathrm{f}}$ values at the end of one year, and the greatest consolidation occurs when applying the $50 \mathrm{~m}^{3} \mathrm{ha}^{-1}$ dose of pig slurry, resulting in a value of 0.28 for $\mathrm{C}_{\mathrm{f}}$. 
2. The pig slurry dose increase results in an increase in the $B_{u}$ values represented by the mass of live and dead roots, and cultural residues incorporated into the soil; after one year, the dose of $200 \mathrm{~m}^{3} \mathrm{ha}^{-1}$ of pig slurry results in the highest value of $B_{u}$, which is equal to $501 \mathrm{lb}^{\mathrm{bcre}}{ }^{-1}$.

3. Pig slurry application onto the soil surface favors the reduction of the Rusle subfactor PLU, and the $50 \mathrm{~m}^{3} \mathrm{ha}^{-1}$ dose of pig slurry is the best option, resulting in a PLU value equal to 0.10 after one year, giving the soil greater resistance to water erosion compared to the other doses studied.

\section{Acknowledgments}

To Conselho Nacional de Desenvolvimento Científico e Tecnológico (CNPq), to Fundação de Apoio à Pesquisa Científica e Tecnológica do Estado de Santa Catarina (Fapesc), and to Coordenação de Aperfeiçoamento de Pessoal de Nível Superior (Capes), for financial support to this research.

\section{References}

ABPA. ASSOCIAÇÃO BRASILEIRA DE PROTEÍNA ANIMAL. Relatório anual: 2016. São Paulo: ABPA, 2016. 133p.

AGNE, S.A.A.; KLEIN, V.A. Matéria orgânica e atributos físicos de um Latossolo Vermelho após aplicações de dejeto de suínos. Revista Brasileira de Engenharia Agrícola e Ambiental, v.18, p.720-726, 2014. DOI: 10.1590/S1415-43662014000700008.

ARRUDA, C.A.O.; ALVES, M.V.; MAFRA, Á.L.; CASSOL, P.C.; ALBUQUERQUE, J.A.; SANTOS, J.C.P. Aplicação de dejeto suíno e estrutura de um Latossolo Vermelho sob semeadura direta. Ciência e Agrotecnologia, v.34, p.804-809, 2010. DOI: 10.1590/S1413-70542010000400002.

BERTOL, I.; BERTOL, C.; BARBOSA, F.T. Simulador de chuva tipo empuxo com braços movidos hidraulicamente: fabricação e calibração. Revista Brasileira de Ciência do Solo, v.36, p.19051910, 2012. DOI: 10.1590/S0100-06832012000600024.

BERTOL, I.; ZOLDAN JUNIOR, W.A.; FABIAN, E.L.; ZAVASCHI, E.; PEGORARO, R.; PAZ GONZÁLEZ, A. Efeito de escarificação e da erosividade de chuvas sobre algumas variáveis de valores de erosão hídrica em sistemas de manejo de um Nitossolo Háplico. Revista Brasileira de Ciência do Solo, v.32, p.747-757, 2008. DOI: 10.1590/S0100-06832008000200029.

CERETTA, C.A.; GIROTTO, E.; LOURENZI, C.R.; TRENTIN, G.; VIEIRA, R.C.B.; BRUNETTO, G. Nutrient transfer by runoff under no tillage in a soil treated with successive applications of pig slurry. Agriculture, Ecosystems and Environment, v.139, p.689-699, 2010. DOI: 10.1016/j.agee.2010.10.016.
COGO, N.P.; STRECK, E.V. Surface and subsurface decomposition of a desiccated grass pasture biomass related to erosion and its prediction with Rusle. Revista Brasileira de Ciência do Solo, v.27, p.153-164, 2003. DOI: 10.1590/S0100-06832003000100016.

COMIN, J.J.; LOSS, A.; VEIGA, M. da; GUARDINI, R.; SCHMITT, D.E.; OLIVEIRA, P.A.V. de; BELLI FILHO, P.; COUTO, R. da R.; BENEDET, L.; MÜLLER JÚNIOR, V.; BRUNETTO, G. Physical properties and organic carbon content of a Typic Hapludult soil fertilised with pig slurry and pig litter in a no-tillage system. Soil Research, v.51, p.459-470, 2013. DOI: 10.1071/SR13130.

CONDÉ, M.S.; ALMEIDA NETO, O.B. de; HOMEM, B.G.C.; FERREIRA, I.M.; SILVA, M.D. Impacto da fertirrigação com água residuária da suinocultura em um Latossolo VermelhoAmarelo. Vértices, v.15, p.161-178, 2013. DOI: 10.5935/18092667.20130024.

CONDÉ, M.S.; HOMEM, B.G.C.; ALMEIDA NETO, O.B. de; SANTIAGO, A.M.F. Influência da aplicação de águas residuárias de criatórios de animais no solo: atributos químicos e físicos. Revista Brasileira de Agropecuária Sustentável, v.2, p.99-106, 2012. DOI: 10.21206/rbas.v2i1.63.

DISSMEYER, G.E.; FOSTER, G.R. Estimating the cover management factor $\mathrm{C}$ in the universal soil loss equation for forest conditions. Journal of Soil and Water Conservation, v.36, p.235-240, 1981.

MECABÔ JÚNIOR, J.; BERTOL, I.; BARBOSA, F.T.; OSELAME, G. de S. Erosão hídrica influenciada por uma aplicação de dejeto líquido de suínos no solo cultivado em semeadura direta. Revisa Brasileira de Ciência do Solo, v.38, p.1601-1611, 2014. DOI: 10.1590/S0100-06832014000500025.

MORAES, M.T. de; ARNUTI, F.; SILVA, V.R. da; SILVA, R.F. da; BASSO, C.J.; DA ROS, C.O. Dejetos líquidos de suínos como alternativa a adubação mineral na cultura do milho. Semina: Ciências Agrárias, v.35, p.2945-2954, 2014. DOI: 10.5433/1679-0359.2014v35n6p2945.

OLIVEIRA, J.G.R. de; BARBOSA, G.M. de C.; TAVARES FILHO, J.; TORRES, E.C. Perda de solo e água e riscos ambientais da concentração de nutrientes no escoamento superficial em solo cultivado no sistema de plantio direto e submetido a adubações orgânicas e mineral. Revista Brasileira de Geografia Física, v.8, p.93-112, 2015.

OLIVEIRA, J.G.R. de; TAVARES FILHO, J.; BARBOSA, G.M. de C. Alterações na física do solo com a aplicação de dejetos animais. Geographia Opportuno Tempore, v.2, p.66-80, 2016.

PRODUÇÃO de suínos: teoria e prática. Brasília: Associação Brasileira de Criadores de Suínos, 2014. 908p.

RAMOS, J.C.; BERTOL, I.; BARBOSA, F.T.; MARIOTI, J.; WERNER, R. de S. Influência das condições de superfície e do cultivo do solo na erosão hídrica em um Cambissolo Húmico. Revista Brasileira de Ciência do Solo, v.38, p.1587-1600, 2014. DOI: 10.1590/S0100-06832014000500024.

RENARD, K.G.; FOSTER, G.R.; WEESIES, G.A.; McCOOL, D.K.; YODER, D.C. Predicting soil erosion by water: a guide to conservation planning with the revised universal soil loss equation 
(Rusle). Washington: United States Department of Agriculture, 1997. 384p. (Agriculture handbook, 703).

RENARD, K.G.; LANE, L.J.; FOSTER, G.R.; LAFLEN, J.M. Soil loss estimation. In: AGASSI, M. (Ed.). Soil erosion, conservation, and rehabilitation. New York: Marcel Dekker, 1996. p.169-202.

SANTOS, H.G. dos; JACOMINE, P.K.T.; ANJOS, L.H.C. dos; OLIVEIRA, V.A. de; LUMBRERAS, J.F.; COELHO, M.R.; ALMEIDA, J.A. de; CUNHA, T.J.F.; OLIVEIRA, J.B. de. Sistema brasileiro de classificação de solos. 3.ed. rev. e ampl. Rio de Janeiro: Embrapa Solos, 2013. 353p.

SCHICK, J.; BERTOL, I.; COGO, N.P.; PAZ GONZÁLEZ, A. Erodibilidade de um Cambissolo Húmico sob chuva natural. Revista Brasileira de Ciência do Solo, v.38, p.1906-1917, 2014a.

SCHICK, J.; BERTOL, I.; COGO, N.P.; PAZ GONZÁLEZ, A. Erosividade das chuvas de Lages, Santa Catarina. Revista Brasileira de Ciência do Solo, v.38, p.890-1905, 2014b. DOI: 10.1590/S0100-06832014000600024.

SILVA, R.F. da; BERTOLLO, G.M.; CORASSA, G.M.; COCCO, L.B.; STEFFEN, R.B.; BASSO, C.J. Doses de dejeto líquido de suínos na comunidade da fauna edáfica em sistema plantio direto e cultivo mínimo. Ciência Rural, v.44, p.418-424, 2014. DOI: 10.1590/S0103-84782012000300006.

STEINER, F.; FEY, R.; ZOZ, T.; COSTA, L. Produção de biomassa e relação $\mathrm{C} / \mathrm{N}$ da aveia preta submetida a fontes e doses de nitrogênio. Global Science and Technology, v.2, p.29-37, 2009.

STOTT, D.E.; STROO, H.F.; ELLIOTT, L.F.; PAPENDICK, R.I.; UNGER, P.W. Wheat residue loss in fields under no-till management. Soil Science Society America Journal, v.54, p.9298, 1990. DOI: 10.2136/sssaj1990.03615995005400010014x.

STRECK, E.V. Erosão hídrica do solo relacionada com o subfator uso anterior da terra do modelo "Rusle". 1999. 195p. Tese (Doutorado) - Universidade Federal do Rio Grande do Sul, Porto Alegre.

STRECK, E.V.; COGO, N.P. Reconsolidation of the soil surface after tillage discontinuity, with and without cultivation, related to erosion and its prediction with Rusle. Revista Brasileira de Ciência do Solo, v.27, p.141-151, 2003. DOI: 10.1590/S010006832003000100015.

VOLK, L.B. da S. Condições físicas da camada superficial do solo resultantes do seu manejo e indicadores de qualidade para redução da erosão hídrica e do escoamento superficial. 2006. 149p. Tese (Doutorado) - Universidade Federal do Rio Grande do Sul, Porto Alegre.

WISCHMEIER, W.H.; SMITH, D.D. Predicting rainfall erosion losses: a guide to conservation planning. Washington: Usda, 1978. 58p. (Agriculture handbook, 537).

WORLD reference base for soil resources 2006: a framework for international classification, correlation and communication Rome: FAO, 2006. 128p. (FAO. World soil resources reports, 103).

$\overline{\text { Received on July 13, } 2017 \text { and accepted on December 18, } 2017}$ 